\title{
SERANGAN DACUS CUCURBITAE ( DIPTERA: TRYPETIDAE) PADA BUAH MENTIMUN DAN PARE YANG DIBUNGKUS PADA SAAT PENTIL
}

\author{
I Gede Swibawa1, F.X. Susilo ${ }^{1}$, Indra Murti $^{2}$, dan Esti Ristiyani ${ }^{2}$
}

\begin{abstract}
Dacus cucurbitae ( Diptera: Trypetidae) attacks on cucumber and peria fruits wrapped at cherelle stage. The fruit flies were important pests of cucumber (Cucumis sativus L) and peria (Memordica charantia L.). The flies attacked fruits by laying egg on the fruit surface and their developing immatures caused serious damages from the inside. The objective of this experiment was to determine the effect of the fruit wrapping at cherelle stage on fruit fly infestation on cucumber or peria fruits. The experiment was conducted in villages of Terbanggi Besar (Central Lampung) and Jati Agung (South Lampung) during October-November 2001. A set of cherelle stage fruits, i.e. those just shed off their florescence, were wrapped using plastic bags while another set of adjacent fruits were left unwrapped. Fruits (treated or untreated) were taken soon after they fell off or at their normal harvest time, whichever came first, then were weighed and incubated in the laboratory to observe the fruit fly emergence. The results showed that fruit wrapping significantly reduced the fruit fly infestation and suppressed the fruit fly population on cucumber or peria fruits. The wrapped fruits weighed more than unwrapped fruits.
\end{abstract}

Key words: Dacus cucurbitae, fruit wrapping, cucumber, peria

\section{PENDAHULUAN}

Mentimun (Cucumis sativus L,) dan pare (Momordica charantia L) adalah tanaman keluarga timun-timunan (Cucurbitaceae) yang banyak dibudidayakan di Indonesia. Kedua jenis tanaman ini merupakan komoditas sayuran penting bagi masyarakat Indonesia. Buah mentimun dikonsumsi dalam berbagai bentuk olahan, namun yang utama adalah sebagai bahan sayuran (Sutarya et al., 1995), sedangkan buah pare yang rasanya pahit karena mengandung momordisin atau charantir digunakan sebagai bahan sayuran dan obat-obatan tradisional (Rukmana, 1997). Baik buah mentimun maupun buah pare dikonsumsi oleh berbagai lapisan masyarakat, sehingga dapat dijumpai mulai dari pasar tradisional sampai super market.

Serangan lalat buah (Diptera: Trypetidae) menjadi kendala dalam budidaya tanaman buah dan sayuran seperti mentimun dan pare. Hama ini dapat mengakibatkan kerusakan buah dengan gejala antara lain (1) bentuk buah tidak normal, (2) buah membusuk, dan (3) buah gugur dini (sebelum waktu panen). Serangan lalat buah dilaporkan dapat menurunkan produksi sesesar 90 \% (Kalie, 1999). Di Indonesia sekitar 12 genus lalat buah telah teridentifikasi. Dacus cucurbitae, D. caudatus dan D. dorsalis adalah tiga jenis lalat buah utama yang menyerang buah tanaman kaluarga Cucurbitaceae (Kalshoven, 1981).
Salah satu teknik pengendalian lalat buah secara non-kimiawi adalah pembungkusan (kondomisasi) buah. Teknik ini dimaksudkan untuk menghalangi aktivitas peletakan telur lalat betina pada buah (Kalie, 1999). Pembungkusan buah telah lazim diterapkan oleh petani di Indonesia, terutama untuk buah seperti nangka, jambu biji, dan tanaman buah lainnya (Kalshoven, 1981). Pada penelitian ini pembungkusan dilakukan terhadap buah mentimun dan buah pare yang masih pentil.

Serangan lalat buah dimulai sejak lalat betina menusukkan ovipositor pada kulit buah untuk meletakkan telurnya yang mengakibatkan gejala berupa bintik-bintik hitam pada kulit buah. Bakteri biasanya terbawa dalam aktivitas ini sehingga buah membusuk (Kalie, 1999). Puluhan butir telur umumnya diletakkan di bawah epidermis kulit buah oleh seekor lalat betina. Telur ini kemudian menetas menjadi tempayak yang aktif memakan daging buah. Serangan ringan menyebabkan buah abnormal sedangkan serangan berat dapat membusukkan dan/atau merontokkan buah (Rukmana, 1997).

Menurut Kalie (1999), pada umumnya lalat buah mendatangi buah yang menjelang masak untuk meletakkan telurnya. Dengan demikian, resiko kerusakan buah dapat dikurangi dengan menghalangi peletakan telur tersebut, caranya antara lain adalah dengan membungkus buah sedini mungkin. Penelitian ini ditujukan untuk mengetahui efektivitas 
pembungkusan buah terhadap serangan lalat buah mentimun dan pare.

\section{METODE PENELITIAN}

Percobaan dilaksanakan di dua lokasi, yaitu pada pertanaman mentimun di Desa Karang Anyar (Kecamatan Jati Agung, Lampung Selatan) dan pertanaman pare di Desa Terbanggi Besar (Kecamatan Terbanggi Besar, Lampung Tengah). Percobaan pada tanaman mentimun dilakukan pada pertanaman berukuran $4 \mathrm{~m}$ x $20 \mathrm{~m}$, sedangkan percobaan pada tanaman pare dilaksanakan pada sepetak areal pertanaman seluas $6 \mathrm{~m}$ x $10 \mathrm{~m}$. Kedua percobaan ini berlangsung dari bulan Oktober sampai November 2001. Baik pertanaman mentimun maupun pare yang digunakan adalah milik petani setempat.

Pada pertanaman mentimun dipilih secara acak sebanyak 20 tanaman. Pada setiap tanaman dipilih sepasang buah muda (berumur satu hari setelah gugurnya mahkota bunga, buah pentil) yang letaknya berdekatan. Duapuluh buah muda yang pertama masing-masing dibungkus dengan plastik polietilin berukuran $4 \mathrm{~cm} \quad \mathrm{x} 20 \mathrm{~cm}$ dan duapuluh buah pasangannya tidak dibungkus (sebagai kontrol). Pasangan buah yang dibungkus dan tidak dibungkus ini diberi label yang berbeda untuk pengamatan selanjutnya. Hal yang sama juga dilakukan pada pertanaman pare.

Panen buah mentimun dilakukan ketika buah berumur $8-10$ hari setelah pembungkusan, sedangkan panen buah pare dilakukan ketika buah berumur 14-17 hari setelah dibungkus. Buah-buah yang gugur sebelum waktu panen juga diambil (dipanen dini). Buah-buah hasil panen ini dibawa ke Laboratorium Hama Artropoda, Fakultas Pertanian Universitas Lampung untuk ditimbang. Selanjutnya, masing-masing buah tersebut diinkubasikan pada sebuah toples plastik (diameter $18 \mathrm{~cm}$, tinggi $20 \mathrm{~cm}$, bertutup kain kasa, dasar toples dilapisi pasir steril setebal $0,5 \mathrm{~cm}$ ) untuk pengamatan kemunculan lalat dewasanya. Lalat dewasa yang muncul dari setiap buah (toples) dicatat jumlahnya dan tanggal kemunculannya, kemudian dikoleksi ke dalam tabung filem berisi alkohol $70 \%$ untuk diidentifikasi. Identifikasi lalat dewasa dilakukan dengan bantuan buku Drew et al. (1978).

Uji Z pada taraf nyata $5 \%$ digunakan untuk membandingkan persentase buah yang memunculkan lalat dewasa dari dua perlakuan (dibungkus versus tidak dibungkus), sedangkan uji t pada taraf nyata $1 \%$ digunakan untuk membandingkan kepadatan lalat buah (yang muncul dari tiap buah) dan bobot buah (dibungkus versus tidak dibungkus).

\section{HASIL DAN PEMBAHASAN}

Setelah diidentifikasi, maka semua lalat buah yang muncul dari buah mentimun atau buah pare, baik yang dibungkus maupun tidak dibungkus adalah Dacus cucurbitae Coquillet (Diptera: Trypetidae). Imago lalat $D$. cucurbitae ini memiliki ciri-ciri toraks dan sayap sebagai berikut (pembeda terhadap jenis Dacus lainnya). Pita costa utuh, sempit, namun melebar pada ujung sayap berupa bercak fuskus gelap yang mencolok (tidak mencapai M1+2, tidak mengenai sel R4+5 di sebelah ujung r-m, kecuali setelah melewati margin depan sayap dan margin $\mathrm{R} 2+3$ ); infuskasi nampak pada $\mathrm{i}-\mathrm{m}$, sel anal dan ekstensi sel anal; rambut skutelum empat helai, vitta tengah di mesonotum berwarna kuning; mesonotum merah kecoklatan. Ciri-ciri tersebut sesuai dengan ciri-ciri D. cucurbitae yang diilustrasikan dalam Drew et al. (1978).

Perlakuan pembungkusan buah pada saat pentil (buah muda) efektif menurunkan tingkat serangan lalat $D$. cucurbitae pada buah mentimun. Buah yang dibungkus terserang $10 \%$, sedangkan buah yang tidak dibungkus terserang $40 \%$. Jumlah lalat yang muncul dari buah yang dibungkus lebih rendah (0,4 ekor/buah) daripada yang muncul dari buah yang tidak dibungkus (1,9 ekor/buah). Bobot buah yang dibungkus lebih tinggi (158,9 g/buah) daripada bobot buah yang tidak dibungkus (127,1 g/buah) (Tabel 1).

Perlakuan pembungkusan buah pada saat pentil (buah muda) juga efektif menurunkan tingkat serangan $D$. cucurbitae pada buah pare. Buah yang dibungkus kurang terserang lalat $(17,5 \%)$ daripada buah yang tidak dibungkus (42,5\%). Jumlah lalat yang muncul dari buah yang dibungkus juga lebih rendah (0,4 ekor/buah) daripada jumlah lalat dari buah yang tidak dibungkus (1,1 ekor/buah). Rata-rata bobot buah pare yang dibungkus lebih tinggi daripada bobot buah yang tidak dibungkus, yaitu 78,5 g/buah versus 34,9 g/buah (Tabel 2).

Munculnya lalat dari 10\% buah mentimun dan $17,5 \%$ buah pare yang dibungkus memang menunjukkan bahwa pembungkusan buah pada saat pentil tidak dapat membebaskan seluruh buah dari serangan lalat buah. Sebaliknya, buah-buah yang tidak dibungkus juga tidak seluruhnya terserang 
Tabel 1. Tingkat serangan lalat $D$. cucurbitae pada buah mentimun yang diberi dan tidak diberi pembungkus pada saat pentil

\begin{tabular}{llcc}
\hline Perlakuan & $\begin{array}{l}\text { Bobot buah } \\
\text { saat panen } \\
\text { (g/buah) }\end{array}$ & $\begin{array}{c}\text { Persentase buah } \\
\text { terserang lalat } \\
(\%)\end{array}$ & $\begin{array}{c}\text { Jumlah lalat } \\
\text { (ekor / buah) }\end{array}$ \\
\hline Buah tidak dibungkus & 127,1 & 40 & 1,9 \\
Buah dibungkus & 158,9 & 10 & 0,4 \\
\hline \multicolumn{1}{c}{$t$ hitung } & $56,9 * *$ & - & $78,0^{* *}$ \\
Z hitung & - & $5,5^{*}$ & - \\
\hline
\end{tabular}

Keterangan: ** berarti nilai $t$ hitung nyata pada taraf $1 \%$;

* berarti nilai Z hitung nyata pada taraf 5\%.

Tabel 2. Tingkat serangan $D$. cucurbitae pada buah pare yang diberi dan tidak diberi pembungkus pada saat pentil

\begin{tabular}{lccc}
\hline Perlakuan & $\begin{array}{c}\text { Bobot buah } \\
\text { saat panen } \\
\text { (g/buah) }\end{array}$ & $\begin{array}{c}\text { Persentase buah } \\
\text { terserang lalat } \\
\text { (\%) }\end{array}$ & $\begin{array}{c}\text { Jumlah lalat } \\
\text { (ekor/buah) }\end{array}$ \\
\hline Buah tidak dibungkus & 34,9 & 42,5 & 1,1 \\
Buah dibungkus & 78,5 & 17,5 & 0,4 \\
\hline \multicolumn{1}{c}{$t$ hitung } & $298,2^{* *}$ & - & $123,7^{* *}$ \\
Z hitung & - & $3,5^{*}$ & - \\
\hline
\end{tabular}

Keterangan: ** berarti nilai $t$ hitung nyata pada taraf $1 \%$;

* berarti nilai Z hitung nyata pada taraf $5 \%$.

lalat buah, melainkan hanya $40 \%$ untuk buah mentimun dan $42,5 \%$ untuk buah pare. Fenomena penyerangan lalat buah pada buah mentimun atau buah pare itu mirip dengan yang terjadi pada buah belimbing (Asrida et al., 2001).

Fenomena serangan lalat buah pada buah dapat diterangkan dengan teori interaksi hamatumbuhan inang. Menurut Kogan (1982), suatu jenis hama akan melawati lima fase di dalam menyerang tumbuhan inangnya, yaitu (1) fase penemuan habitat tumbuhan inang, (2) fase penemuan tumbuhan inang, (3) fase pengenalan tumbuhan inang, (4) fase penerimaan tumbuhan inang, dan (5) fase kecocokan tumbuhan inang. Pembungkusan buah mentimun atau pare pada saat pentil dimaksudkan untuk menggagalkan lalat buah $D$. cucurbitae dalam melawati fase 3, yaitu pengenalan tumbuhan inang. Pembungkusan buah diharapkan dapat menggagalkan lalat betina dalam mengenali tumbuhan inangnya (buah), sehingga oviposisi tidak terjadi pada buah yang dibungkus (lalat gagal memasuki fase 3). Data persentase buah terserang lalat pada Tabel 1 dan 2 mengindikasikan bahwa lalat betina (tetua) masih memiliki peluang 0,1 (pada mentimun) dan $<0,2$ 
(pada pare) dalam mengenali buah dan melakukan oviposisi pada buah yang telah dibungkus saat pentil, sehingga lalat buah berhasil memasuki fase 3. Bahkan fase 4 dan 5 pun berhasil dilampaui (ditunjukkan oleh munculnya imago lalat zuriat dari buah yang diinkubasi yaitu, 0,4 ekor/buah pada mentimun dan 0,4 ekor/buah pada pare. Fenomena ini membangkitkan pertanyaan sebagai berikut. (1) Apakah oviposisi sudah terjadi saat buah belum menjadi pentil (saat fase bunga)? Dengan kata lain, betulkah lalat betina (tetua) sudah meletakkan telurnya saat buah mentimun atau pare belum dibungkus? (2) Bila betul demikian, bukankah serangan yang sangat dini itu merupakan mekanisme pengguguran buah yang normal pada tanaman mentimun atau pare untuk mengurangi kompetisi nutrisi antar-buah pada kedua tanaman ini, seperti yang misalnya terjadi pada tanaman coklat (Theobroma cacao)? Tanaman coklat melakukan pengguguran buah pentil dini melalui mekanisme fisiologis (physiological thinning effect), untuk mengurangi kompetisi nutrisi antar-buah (Siregar et al., 1999).

Sebaliknya, buah yang tidak dibungkus tidak seluruhnya diserang lalat tetapi hanya $40 \%$ (pada mentimun) dan 42,5\% (pada pare). Mungkinkah lalat betina (tetua) "sengaja” membiarkan sebagian buah untuk dapat berkembang normal sampai masak dan menghasilkan biji untuk menghasilkan tanaman baru berikutnya sebagai sumber makanan bagi zuriatnya?

\section{SIMPULAN}

Jenis lalat buah yang ditemukan menyerang mentimun atau pare adalah Dacus cucurbitae. Pembungkusan buah saat pentil efektif menurunkan tingkat serangan lalat buah, menekan jumlah lalat buah yang muncul dari buah dan mengurangi kehilangan bobot buah mentimun atau pare.

\section{SANWACANA}

Bapak Supono dan Bapak Supri masingmasing adalah pemilik pertanaman mentimun dan pare yang telah mengijinkan pertanamannya digunakan sebagai lokasi percobaan. Dalam kesempatan ini penulis mengucapkan terima kasih kepada beliau berdua. Penulis juga mengucapkan terima kasih kepada Bapak Ir. Nuryasin, M.Si. dan Ibu Ir. Lestari Wibowo, M.S. yang telah banyak menyumbangkan pemikiran dan bantuan dalam penyelesaian penelitian ini.

\section{DAFTAR PUSTAKA}

Asrida, E., F.X. Susilo \& L. Wibowo. 2001. Respons berbagai jenis lalat buah belimbing terhadap pembungkusan buah. Jurnal Penelitian Sains dan Teknologi 7 (1): 76—86.

Drew, R.A.I., G.H.S. Hooper, \& M.A. Bateman. 1978. Economic Fruit Flies of the South Pasific Region. Watson Ferguson, Brisbane.

Kalie, M.B.1999. Mengatasi Buah Rontok, Busuk, dan Berulat. Penebar Swadaya, Jakarta.

Kalshoven, L.G.E. 1981. The Pests of Crops in Indonesia. (Rev. \& Transl. by P.A. van der Laan \& G.H.L. Rothschild). PT Ichtiar Baruvan Hoeve, Jakarta.

Kogan, M. 1982. Plant resistance in pest management. Pages 93-134 in: Metcalf, R.L. \& W.H. Luckman, eds. Introduction to Insect Pest Management. $2^{\text {nd }}$ ed. John Wiley \& Sons, New York, etc.

Rukmana, R.1997. Budidaya Tanaman Pare. Kanisius, Yogyakarta.

Sutarya, R., G. Grubben, \& H. Sutarno. 1995. Pedoman Bertanam Sayuran Dataran Rendah. Universitas Gadjah Mada, Yogyakarta.

Siregar, T. H.S., S. Riyadi, \& L. Nuraeni. 1999. Budidaya, Pengelolaan, dan Pemasaran Coklat. Penebar Swadaya, Jakarta. 
Tabel 1. Tingkat serangan lalat $D$. cucurbitae pada buah mentimun yang diberi dan tidak diberi pembungkus pada saat pentil

\begin{tabular}{llcc}
\hline Perlakuan & $\begin{array}{l}\text { Bobot buah } \\
\text { saat panen } \\
\text { (g/buah) }\end{array}$ & $\begin{array}{c}\text { Persentase buah } \\
\text { terserang lalat } \\
\text { (\%) }\end{array}$ & $\begin{array}{c}\text { Jumlah lalat } \\
\text { (ekor / buah) }\end{array}$ \\
\hline Buah tidak dibungkus & 127,1 & 40 & 1,9 \\
Buah dibungkus & 158,9 & 10 & 0,4 \\
\hline \multicolumn{1}{c}{$t$ hitung } & $56,9 * *$ & - & $78,0^{* *}$ \\
Z hitung & - & $5,5^{*}$ & - \\
\hline
\end{tabular}

Keterangan: ** berarti nilai $t$ hitung nyata pada taraf $1 \%$;

* berarti nilai Z hitung nyata pada taraf 5\%.

Tabel 2. Tingkat serangan $D$. cucurbitae pada buah pare yang diberi dan tidak diberi pembungkus pada saat pentil

\begin{tabular}{lccc}
\hline Perlakuan & $\begin{array}{c}\text { Bobot buah } \\
\text { saat panen } \\
\text { (g/buah) }\end{array}$ & $\begin{array}{c}\text { Persentase buah } \\
\text { terserang lalat (ekor/buah) } \\
(\%)\end{array}$ & Jumlah lalat \\
\hline Buah tidak dibungkus & 34,9 & 42,5 & 1,1 \\
Buah dibungkus & 78,5 & 17,5 & 0,4 \\
\hline \multicolumn{1}{c}{$t$ hitung } & $298,2^{* *}$ & - & $123,7^{* *}$ \\
Z hitung & - & $3,5^{*}$ & - \\
\hline
\end{tabular}

Keterangan: ${ }^{* *}$ berarti nilai $t$ hitung nyata pada taraf $1 \%$;

* berarti nilai Z hitung nyata pada taraf 5\%. 